\section{Processes of Commercial Territorialization in the Polycentric Region of the Marche. New Commercial Hierarchies in the Doric Capital} of Commercial Territorialization in the Polycentric Region of the Marche. New Commercial Hierarchies in the Doric Capital. Bollettino della Società Geografica Italiana serie 14, 3 Special Issue: 117-125. doi: 10.36253/bsgi1001

Copyright: (c) 2020 C.M. Porto. This is an open access, peer-reviewed article published by Firenze University Press (http://www.fupress.com/bsgi) and distributed under the terms of the Creative Commons Attribution License, which permits unrestricted use, distribution, and reproduction in any medium, provided the original author and source are credited.

Data Availability Statement: All relevant data are within the paper and its Supporting Information files.

Competing Interests: The Author(s) declare(s) no conflict of interest.

\section{Processi di territorializzazione commerciale nelle Marche policentriche. Nuove gerarchie commerciali a partire dal capoluogo dorico}

\author{
Carmelo Maria Porto \\ Dipartimento di Scienze cognitive, psicologiche, pedagogiche e degli studi culturali, Uni- \\ versità di Messina, Italy \\ E-mail: cporto@unime.it
}

\begin{abstract}
The gradual modernization of commercial activities during the past 20 years has had a deep impact on the urban landscape of Ancona and has strongly affected the stable relationship that for decades had marked the city center and its suburbs. The traditional hierarchy of commercial areas has undergone a new configuration due to suburban territorialization processes brought by a large-scale polarization of the city's suburbs. Understanding these new commercial hierarchies represents a valid tool for planning proper territorial policies and boosting more resilient-based processes which aim at restoring the primary role of a city center that has slowly lost its social appeal and its functional status-quo within the city's metropolitan area and in the urban network of the Marche.
\end{abstract}

Keywords: territorialization, distribution system, polycentrism.

\begin{abstract}
Riassunto. La progressiva modernizzazione commerciale, che ha investito il territorio marchigiano nell'ultimo ventennio, ha profondamente mutato il paesaggio urbano anconetano ed ha influito in maniera significativa sul mantenimento dellequilibrato rapporto centro-periferia che aveva caratterizzato per decenni il sistema urbano gravitante sul Capoluogo. La configurazione di nuove gerarchie commerciali, come conseguenza dei processi di territorializzazione suburbana innescati dalle grandi polarizzazioni extra-urbane, può rappresentare una valida chiave di lettura utile a suggerire politiche territoriali appropriate e in grado di innescare processi resilienti utili a restituire un ruolo di primo piano al centro storico della città che nello stesso periodo a visto via via diminuire la sua capacità attrattiva e di conseguenza la sua supremazia funzionale verso l'area metropolitana e i più in generale nei confronti della complessa e fitta maglia urbana marchigiana.
\end{abstract}

Parole chiave: Territorializzazione, sistema distributivo, policentrismo. 


\section{Consumer Models and Polycentric Relationships in Ancona}

Consumer areas are a main factor in determining contemporary re-structuring of urban and suburban territories thus replacing the past urban model of the factory town and the post-Fordist city. These processes are especially evident when looking at the increasing space occupied by activities linked to the traditional and nontraditional tertiary and commercial sector. Although these changes have helped in shaping new urban layouts of several territorial systems, they have also strongly contributed to the commercial desertification of many city centers which, ever since the early 90 's, has invested many Italian and European cities. This spatial shift towards the outer area of the city and its suburbs has redefined past territorial balances and shaped new multicentric and/or polycentric urban areas depending on what was the city's structure prior to the diffusion of the phenomenon (Bullado 2007a; Porto 2019).

Modern cities have responded to changes brought by deindustrialization processes of urban economies by progressively allowing consumer activities to permeate their structures up to the point of ousting production ones (Meini, Monheim 2002; Carreras, García Ballestreros 2006; Bullado 2007b, 2009; D’Alessandro 2015; Cirelli et al. 2016). As a consequence of these transformations, contemporary cities are special and sometimes even surreal or fantasy places "[...] where shows are associated to art, museums but also to shopping venues: new places are born in substitution of past squares and streets where people can meet and socialize like shopping malls, airport lounges, theme parks and all those - more or less - artificial places designed by an everchanging society" (Miani 2001, 48).

Consumer habits in their most advanced form can deeply alter the territory and its community creating new socialization venues that meet the fast-paced metamorphosis of modern consumer behaviors which are, by these same places, further influenced and affected in the unfolding of these activities. The result of this paradigm is that places originally meant for commercial or socialization activities (including political and religious buildings) that have contributed in forging Italian cities' layout for the past centuries have been abandoned in favor of new surroundings like suburban areas and their main transit routes (Porto 2016). These new areas are artificially designed for socializing activities and are today's substitute of the lively atmosphere which used to be a prerogative of city centers only. The city - which in its oldest sense was meant as a public space - has been re-placed by a consumer-designed city. The performance of consumer activities has become in Ilardi's words “[...] the organizational principle in relationships among individuals and among individuals and goods" (Ilardi 2004, 21).

This evolutionary framework of city-trade-consumer relations seems to prefer vaster and artificially planned suburban areas where entertainment represents the most effective drive-in promotional policies thought for contemporary consumers. In view of such political strategies which generate "[...] temporary convergences of social interactions that are independent from the background in which they take place and, to a certain extent, are typically traceable in non-places, [...] city centers are called to answer using tools that can remove inbuilt limitations and restore their leading convergence role, not only commercially but also socially, civically and culturally" (Musso 2012, 161).

It must however be noticed that especially in the Anglo-Saxon world but also in France, Spain and even more in Germany, there has been a partial turnaround in the past twenty years, regarding GDO location choices and moreover in respect to the mega shopping venues which have started to relocate in the city centers thanks to the re-functionalization of old spaces like historic buildings, dismissed urban industrial areas and interstitial voids left over by the turbulent expansion of cities begun in the mid-20 $0^{\text {th }}$ century (Cavoto, Limonta 2015). Such phenomenon, often stigmatized in current literature with the expression "back to downtown" mainly concerns big industrial and manufacturing towns as well as the big financial cities (Zanderighi, Tamini 2018).

It is within this corollary that the present work inserts itself without wanting to be in any way exhaustive. This paper rather aims at adding a piece to the mosaic of a more complex research topic that has already been addressed in the PRIN 2015 "Retail, Consumption, and the City: Practices, Planning and Governance for Urban Inclusion, Resilience, and Sustainability". The latter offered an empirical way of testing if an urban polycentric system (like that of the Marche) - compared to a polarized one - is more apt to implement policies which aim at granting a "complementary" approach among "traditional" distribution models using more modern formats. The above-mentioned test took into consideration the areas included in the provinces of Macerata, Fermo and Ascoli and left out (due to lack of time and resources) the metropolitan area of Ancona (Nicosia, Graziano, Porto 2019). It was thus natural to further continue the investigation, without granting the same level of detail, in the attempt of offering a better over-view on the topic. 
In order to understand the role of Ancona, the Region's capital, in the economic and commercial dynamics of the Marche, it is important to refer to the concept of plural region. This idea does not have a straightforward meaning as it is linked to the complex identity of the Marche. The historian Sergio Anselmi, in the 1980's described his region in the following terms.

"A marginal rectangle, sleepy and full of tenant farmers, situated between the north and south of the Adriatic coast: this was until the late 50's the general way of picturing the Marche, a place from which to escape as many had already done back in the 1800's [...] the leap forward that marked the 1950's up to the 70's significantly changed the Marche and yet its past tenant-farming background, with its hundreds of small towns, villages ${ }^{1}$, fractions of land well framed in the territory, together with the widespread presence of the tenancy-based cultural system which has become more refined due to contacts with the urban environment (today the Marche counts four Universities offering all kinds of courses, Art Academies and Musical Institutions), contribute to forging the region's exclusive and gentle imprinting" (Anselmi 1985, 9-11).

From a functional point of view, the urban network of the Marche, is marked by a complementary-based relation (especially for more important services) between the eleven Urban Functional Areas (Aree Funzionali Urbane) identified on the territory. These areas basically involve slightly more than 30 towns/villages out of the over 200 present in the region. This urban model is strongly characterized by a natural form of urbanization which is widespread across the land and is further confirmed by population data. Although there are more than 200 small towns scattered across the region, just 16 count more than 20.000 inhabitants and Ancona is the only town with a population slightly above 100.000 (Nicosia, Porto 2015).

The polycentric urban nature of the Marche is the result of its morphological layout - a coastline connected to its inland by a variety of plains, hills, valleys and mountains - and the organization of agricultural activities of tenant farmers (Nicosia, Porto 2015). The development of industries during the second half of the 1900's produced a crisis in the traditional organization of rural land and caused farmers to shift, first to Rome and the industrial towns of northern Italy and then to the coastal towns, so that the settlements in the hills, in the absence of manufacturing activities, turned into empty shells, while the valley villages and the towns of

\footnotetext{
${ }^{1}$ The population of the Marche is of 1.525.271. This figure represents slightly more than $2,5 \%$ of Italy's national population in 01.01 .2019 . The population of the Marche is distributed in 246 different municipalities $50 \%$ of which has a population of less than 3.000 (ISTAT 2018).
}

the plains and along the coast kept on growing chaotically. During the last thirty years, changes in the production structures have had a strong impact on population distribution as well as on local economy. The preexisting gap between the coast, rich in various types of settlements, and the hills-mountains, mainly scattered with nuclei and centers, has grown deeper. (Betti 2002, 186). This has broken the geographical distribution of the entire and rather homogeneous Region, which had lasted for centuries; the Province of Ancona has nowadays a population density twice that of Macerata and Pesaro-Urbino. Although its polycentric organization, the territory of the Marche is characterized by a growing dualism between the coast (33\% of the territory) and the hill (36\%) and mountain (31\%) areas (Betti, Nicosia, Porto 2011).

This territorial re-arrangement brought about by infra-regional migration flows towards the coast land, has contributed in shaping a linear urbanization of the region that runs along the entire seacoast and is physically interrupted by the Conero Mountain. Ancona is the most populated town (slightly above 100.000) of this urban continuum followed by Pesaro, Fano, Senigallia, Civitanova Marche and San Benedetto del Tronto. A point of further interest is that among these towns, only Ancona and Pesaro-Urbino are two district capitals.

Ancona, regional and district capital, is the hierarchically superior town within the complex urban network of this plural region. This superiority however is not ascribable only to its historical and institutional importance but also to its strategic position that ever since its foundation has turned it into one of the main commercial harbors of the Adriatic Sea. Ancona is the most important harbor of the region also due the level of its infrastructures which make it the most accessible city of the Marche and strengthens its competitiveness in terms of geographical location along the Adriatic coastline.

\section{Commerce, consumer habits and modernization processes in Ancona}

The commercial modernization process which has affected Italy and the Marche's sales system, especially in the last two decades, has had a strong influence in re-shaping the urban planning of Ancona - more than other regional capitals - thus powering the rise of the suburbs which have acquired a new centrality outside the traditional city center.

The present work follows the traditional model based on the opposition center-suburbs as the starting 
point for the analysis. This "weak" transcalar methodological approach allows to investigate and describe spatial areas using the opposition scheme center versus suburb. It is defined as "weak" because it is applicable at different spatial scales and sizes (economic and territorial development, hierarchy, political influence). It is in contrast with a "strong" transcalar methodology which is based on the joint study of different spatial scales linked together by an ensemble of physical connections (Bonavero 2005).

This opposition between the traditional commercial offer of the city center in contrast to the modern shopping system strategically positioned along the main transit routes, can be a useful tool in identifying strong points and weak points of both models in order to build policies that foster integration and complementarity to better suit recent consumer trends and leisure activities in general.

This study offers an analysis based on the municipal scale although administrative borders have not always been strictly respected in order to reach a wider comprehension of the suburban shopping agglomerations (Southern Suburb) that contribute in creating an urban concentration that stretches out for several kilometers and incorporates neighboring towns. The south industrial/commercial area, more specifically, runs for more than 10 kilometers unfolding along the main transit routes of minor towns like Candia, Vara and Angeli as well as the towns of Camerano and Osimo.

This work's focus is the territory between the city center and the Industrial area Baraccola (Southern Suburb). The latter has a very heterogeneous urban structure not always easy to interpret. It presents many past urban layers. It is a mix of buildings of different styles and periods and the morphological structure itself is the result of an often chaotic urban planning.

Data used for the investigation concerning the shopping dynamics of the past two decades has been mainly provided by local institutions, in particular the Office for the Economic Affairs of the municipality of Ancona and the Chamber of Commerce. Other information was also gathered via other institutions, local companies of the area of interest, specific case studies and local newspaper articles.

The Doric Capital is the only urban system of the Marche that has a more metropolitan - however weak - type of configuration. This is not only because of its demographic superiority compared to the other towns of the region and its territorial extension but also because of its core role as a provider of administrative services (locally and regionally), resources and facilities.

The modernization of the local distribution system starts at the end of the 90's and becomes more intense the following decade also thanks to the Bersani reform and the Legislative Decree 114/98.

Changes are particularly evident in the Southern Zone. In a time span of ten years this area has experienced a strong boost in the commercial building sector which has consequently led to the expansion of the main transit roads of this peripheral territory. The area of highest commercial/industrial density includes the Baraccola Zone and the districts of Osimo and Camer$\mathrm{ano}^{2}$.

The presence of many manufacturing/logistics companies and pre-existing infra-structures together with the territorial configuration of the valley that grants fast connections between the Southern Industrial districts (Osimo-Camerano and Castelfidardo-Recanati) and Ancona, have been crucial elements in recent urban planning decisions.

The very first large-scale retailer to open at the beginning of the 90 's was the shopping center Joyland (acquired in 2002 by Auchan). In the early year 2000's other large retailers followed this trend like Ikea (in the area of Camerano) and the shopping park Cargopier (in Osimo Scalo). Nowadays the province of Ancona has the highest concentration of shopping centers (nine in total) on a regional basis. The Auchan shopping gallery covers 7.320 square meters, counts 42 stores and provides 1600 roofed parking spaces. It represents the most established shopping space of the area and has increased its commercial power over the years becoming also an important socializing spot for younger generations.

Other important retail stores are located nearby. Megastore Expert is a chain of electronic retailers and occupies a surface of 2.500 square meters whereas Globo Cosmo with a surface of 5.300 square meters is the biggest retailer of the fashion and footwear industry. The modern Extasy Busco is a mega sports center with pools, gyms and beauty centers which also offers shopping facilities and has even a post-office. Another impor-

\footnotetext{
2 This area runs along the valley of the river Aspio. It is crossed in its entire length by the Adriatic route and includes the districts of Ancona, Camerano and Osimo. This territory also reaches the area of Castelfidardo, however most of the urbanization process here is mainly linked to the industrial sector and only marginally counts some exclusively commercially designed areas. The territory subject of this study is situated along the flat stripe of land of the Aspio valley and is delimited by two hillsides. It includes the Industrial Zone Baraccola (Ancona) on the north, Osimo Stazione on the south (part of Osimo) and Aspio Terme (district of Camerano) in the middle. The shopping/industrial spaces are positioned along the main transit route SS16 which connects Southern Ancona to the motorway A14. There also two important train stations and the so called Asse Nord-Sud which is an important national road that grants rapid access to the Sirolo-Senigallia main transit route (SP2) and links southern districts to the inner parts of Ancona.
} 


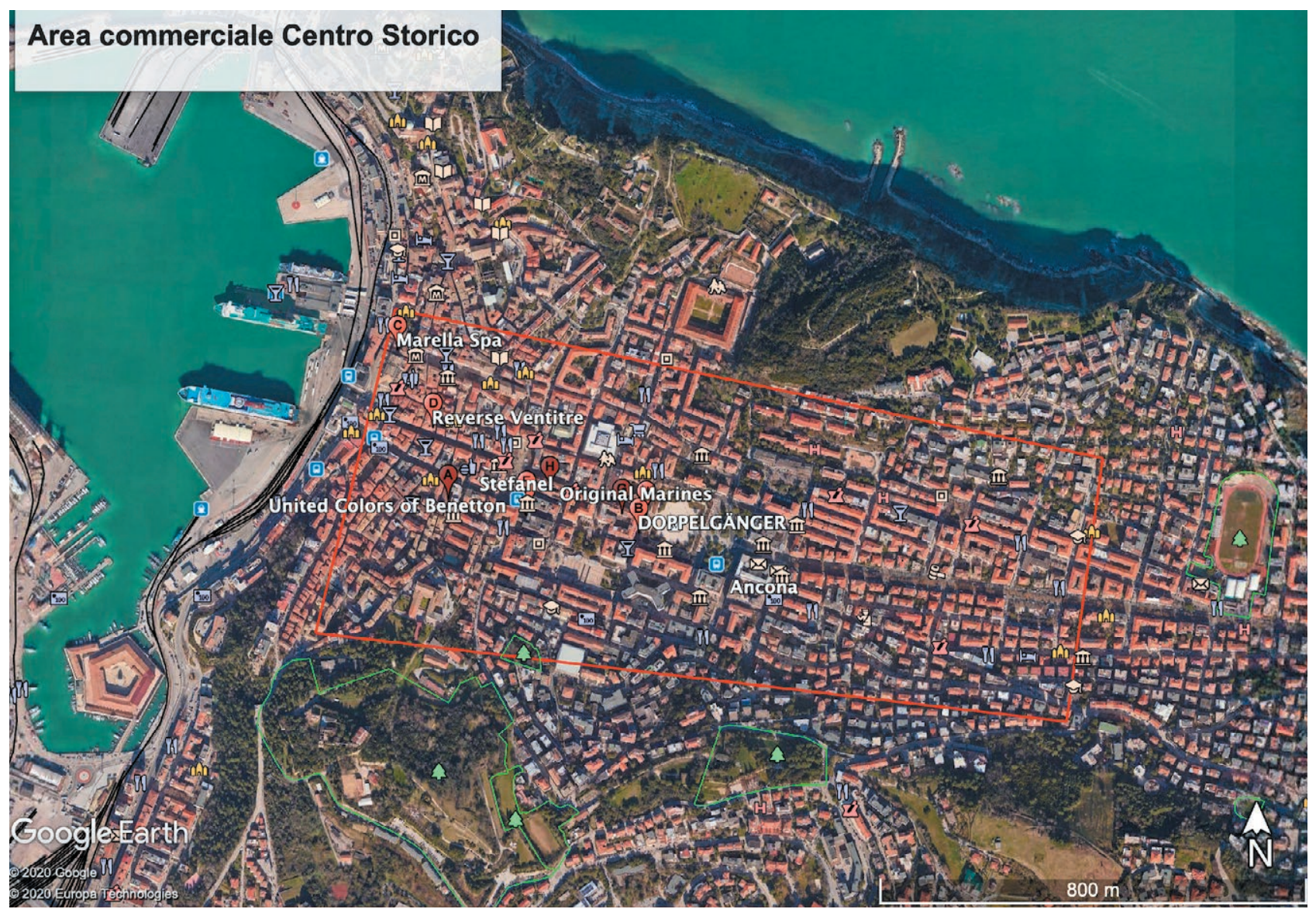

Figure 1. Retail Area Historic Center.

tant center specialized in the entertainment sector with 9 movie theaters, game rooms, restaurants and other related activities, is the Uci Cinema or former Multiplex Girometti which is also close to a Mc Donald's chain. The Baraccola zone surely marks the starting point of this modernization process which has also invested the areas of Camerano and Osimo. Nevertheless, the arrival of other mega industries of the sales industry like MediaWorld (2.600 sqm) and Pittarello Calzature (1000 sqm) has further strengthened the commercial attractiveness of Baraccola (figures provided by the Chamber of Commerce).

Special attention deserves the Ikea store situated in Aspio in the Camerano district. The Swedish mega furniture company opened its first shop in the Marche in 2006 after heated debates concerning land and viability issues. It counts almost 25.000 square meters of exhibition area and is thus the biggest furniture store of the region (www.ikea.com).

The opening of the Ikea store with its infra-regional catchment area has undoubtedly contributed in enrich- ing the overall economic flow of the Marche but has also had the counter effect of damaging local small and medium sized businesses. The increase of car flow consequent to the store's activities has also made upgrades (financed by Ikea and public institutions) to pre-existing infrastructures necessary. These include roundabouts, double-track roads and the small train station of Aspio situated in the store's car park. Always in Camerano, the Carrefour shopping center and the Conbipel store also deserve a quick mention.

Cargopier is another important shopping center located in Osimo Stazione and built in 2004. It covers 23.000 square meters and provides 1.200 car park spaces. There are 32 shops in total and the biggest building hosts famous retail chains like Oviesse, Euronics, Brico Io, Risparmio Casa and the food discount shop Dico. The second building is a more recent construction and is occupied by smaller franchise dealers.

In terms of consumer goods, the commercial offer of the city is mainly specialized in long term items rather than food products. Most stores belong to the electron- 


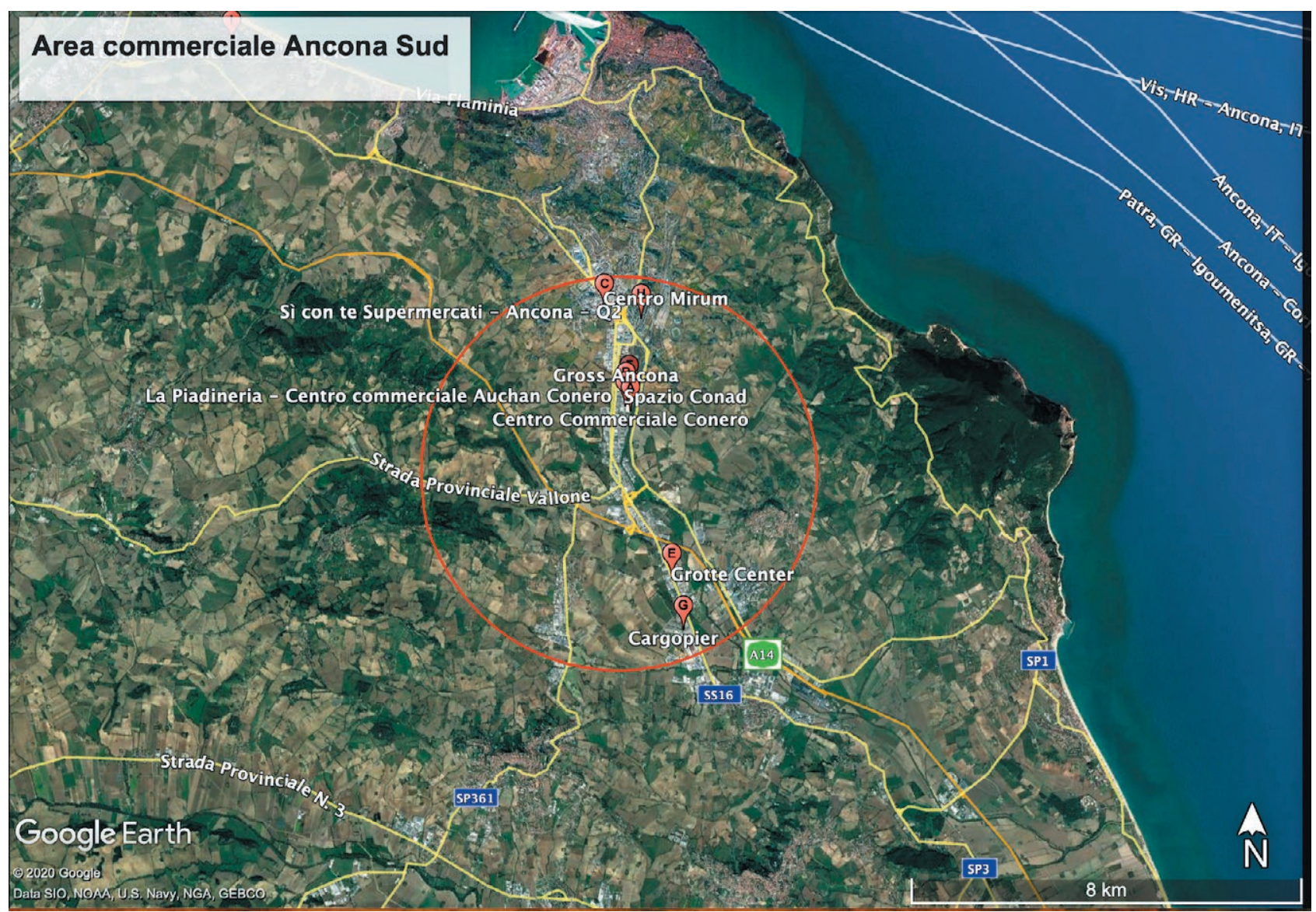

Figure 2. Retail Area Ancona Sud.

ic, fashion, household/furniture and hobby sector. Taking advantage of the vast exhibition spaces available, the Southern Zone is more into electronic and furniture products whereas small retailing businesses are more popular in the central zone.

Large-scale food retailers are also more present in the Southern Zone where there are several hypermarkets of famous food chain distributors. Supermarkets leave room to local groceries and smaller shops selling traditional or ethnic food in the central zone.

Data collected from a quantitative analysis of the commercial businesses active in Ancona confirm the long-term crisis that has invested this sector. In less than 10 years time, Ancona has lost more than 400 businesses (from 3000 registered activities in 2009 to 2.638 in 2018). Two facts are immediately observable. The first is that during the years taken into account, all annual tendential variations are negative. The second is that since 2009 there has been a business decline of over $13 \%$ which is a significant figure. (Chamber of Commerce 2018).
The city center of Ancona stretches towards northeast along the Guasco hill - with its beautifal San Ciriaco cathedral - and the Astagno hill characterized by the renaissance military construction named "Cittadella".

The center of the town is crossed from east to west by a transit route that splits the city in two and connects the harbor to the rocky beaches of Passetto thus linking the two seas of Ancona. This axis route is made in its first part by three parallel roads (Corso Stamira, Corso Garibalidi and Corso Mazzini) which join in Piazza Cavour (main square) and continue as one main boulevard (Viale della Vittoria) until the Passetto monument which conventionally marks the boundaries of the town's center.

The city center is technically marked by the area surrounded by the town's $19^{\text {th }}$ century walls and delimited by the harbor on one side and Piazza Cavour on the other. The overall heterogeneous architecture of the buildings however does not always guide the viewer's 
sight towards this perception. The area is in fact the result of centuries of urban stratification and juxtaposition of past Doric architecture, world war remaining constructions and modern buildings of recent times.

The city's center is thus characterized by the three parallel roads previously mentioned and four main squares. Piazza del Plebiscito (also known as the Pope's Square) near the oldest part of the city, Piazza della Repubblica with its Teatro delle Muse (theatre) close to the harbor, Piazza Roma which is also the shopping heart of the town and finally Piazza Cavour with its typical $19^{\text {th }}$ century style. There is also the modern Piazza Pertini near Corso Stamira.

Most of the administrative offices and municipal buildings are placed in this town area whereas shops and general retailing activities are traditionally found along the three main roads. Back until the $19^{\text {th }}$ century the so called Pope's Square used to be the commercial heart of the town but it lost its urban pole-position after the building of the theatre (Teatro delle Muse) near Piazza della Repubblica and the construction of Piazza Roma. In recent years however, Pope's Square seems to have regained its past liveliness thanks to the opening of new pubs and the full pedestrianization of the area. The beauty of its buildings is also an extra incentive for open-air forms of socialization.

The contemporary layout of the city center is therefore marked by this clustering of services, facilities and leisure time areas within the space enclosed by these three squares. This is why we can consider Ancona a polycentric type of town.

The older parts of the city, situated near the Guasco hill, seem cut-off from this urban cluster. This is probably ascribable to its morphological asset. The ancient little streets which unfold up and down along the hill, hinder viability and accessibility which are essential requirements for commercial activities and public services. Nevertheless, thanks to the cultural and architectural heritage of this area, important projects have been developed to further enhance this part of town and promote its attractiveness also to non-local residents.

Many important institutions are situated in this area like the National Archeological Museum of the Marche, The Civic Art Gallery "Podesti", the Modern Art Gallery, the City's Museum, The Faculty of Economy of the Polytechnic of the Marche, Italy's Military Training School and other financial/administrative buildings.

Like many old Italian towns, viability and accessibility are big issues due to their urban network which is usually marked by small central streets (only suitable one-way car traffic) and due to a massive convergence of administrative facilities and local governance offices in the city center. Another problem is connected to a natural lack of car-parking spaces. Although roofed or underground car parks - for instance in Piazza Pertini have been built in recent years, car flows coming in and out of town are still an open issue in terms of traffic efficiency.

This mismanaged traffic congestion negatively affects the city's appeal and its livability which are two essential conditions for fostering the growth and development of commercial activities inside the city center. This consequently influences people's preference towards more accessible extra-urban shopping areas.

This slow process of commercial desertification, which seems affecting especially medium sized cities in Italy, has of course weakened the polarizing pull of the city center. In the case of Ancona, traffic has shifted in both directions of the Adriatic route (north towards Pesaro and south towards San Benedetto del Tronto) thus generating a more polycentric re-arrangement of the Marche's urban system.

Traditional shops situated in the town's center which offered typical local goods, have been replaced by the standardized offer of franchise companies whose windows not only have strongly changed the shopping landscape of the old Ancona, but have also weakened its past identity.

Although the city center counts four main squares, it is the area in Corso Garibaldi and Piazza Roma that constitutes the true hub of commercial activities and weekend strolling. Most of the shops here are specialized in clothing and accessories. There are still some traditional old shops that, for the time being, survive the occupation of franchising chain-stores whose low-cost offer is especially appealing to younger targets of consumers. Most of these clothing brands (Terranova, Benetton or Zara) sell fast fashion goods and are a typical example of global-shopping consumer culture. The old tailoring boutique Belvederesi (open for over 50 years) and the clothing shop Rinaldi have both been replaced in Corso Garibaldi by other retailing businesses of the global industry.

Quite often, shops seem to prefer locations on the side streets of Corso Garibaldi like via Lata, via degli Orefici and at the beginning of Corso Mazzini where rents are higher. This increase of property values has also allowed an upgrade in terms of attractiveness of the area near Pope's Square as confirmed by localization tools provided by the Apple Center.

It is therefore questionable whether the city center of Ancona - already under pressure to satisfy modern needs and embrace a more or less drastic change 
- has what it takes to integrate the expansionist and functionalist approach of modern businesses, mainly focused in the suburbs, without damaging the typical shopping landscape of the city, thus setting an example for a sustainable economic and urban development (Porto 2007).

Furthermore, if Ancona's urban regeneration has fostered an economic recovery, it is also true that the commercial growth of recent years, with all its imperfections, has strongly contributed in speeding-up processes concerning urban improvements.

Some of these upgrading measures are worth mentioning and include the stone paving in Corso Garibaldi (2009), the introduction of car-free areas in central streets and the introduction of LED technology for streetlights (exquisite mix of design and energetic efficiency). The latter is the result of a joint project which involved Ancona's Municipality, the company Enel Sole, the institution Anconambiente and a group of local business retailers.

\section{Final Considerations}

The gradual modernization of commercial activities during the past 20 years has had a deep impact on the urban landscape of Ancona and has brought to the rise of suburban centers. Although this slow process of urbanization involves the city's peripheral area, it is not easy to mark clear boundaries as it invests the municipality of Ancona as well as some of its neighboring districts.

A balanced set of policies that promote territorial enhancement, efficient urban planning and foster the economic growth of the city, in particular its center, is highly recommended, especially after the devastating economic effects of the COVID19 pandemic lock-down. The confining measures imposed by governments have temporarily stopped the competition between the retailing activities of the city-center and its suburbs. This economic setback can however be an opportunity to plan new spaces and re-think best practices more fit for latest social distancing requirements.

With this in mind, a more complementary/cooperative-based commercial urban system would be desirable, rather than focusing on territorial competition, so as to integrate modern consumer needs with traditional commercial activities. Such co-existence can pave the road to a more sustainable and functional urban reality.

The ghettoization of the city center during the last decade seems slowly diminishing as a consequence of a growing awareness of local communities towards this phenomenon. Policies of urban regeneration and the recovery of public spaces have led to a rise of visitors and have gradually boosted economic growth and cultural activities which proves how the commercial sector can be a strong shareholder for urban regeneration processes.

It is therefore important to adopt policies that are well aware of the complexity of Ancona's urban system and its commercial network. Urban planning should focus on improving the level of the town's accessibility and its attractiveness without however, compromising the city's identity and livability.

It would also be desirable a governance capable of cooperating with all the stakeholders of the private and public sector that share the common interest towards the development of Ancona's city center. The ultimate aim should be to preserve the town's historical and social heritage whilst promoting a mindful economic and commercial growth.

As far as the Southern Zone, is concerned it is evident that it has reached a spatial market saturation. The opening of new shopping areas in fact often causes the shutting down of other pre-existing businesses or end up in an economic failure due to their unsustainability within that given marketplace.

Although this area is important for economic and occupational reasons, it also presents many critical factors, for instance the loss of economic and functional power of the minor towns located nearby. In fact, where as Ancona's center still - at least partially - manages to attract visitors re-claiming its role as the region's hotspot, the survival - from a functional point of view - of minor towns is at risk due to this process of desertification. The only municipality, besides Ancona, that appears to be strong enough to compete with modern shopping areas by re-affirming the traditional commercial power of the urban center, is Riviera del Conero which is a very popular tourist destination and offers a range of high-quality local goods.

Problems and future solutions concerning Ancona, overall may result not straightforward to understand due to the complex relationship between the city and its network of commercial activities. Although the changes affecting this territory are the result of mechanisms ascribable to globalization, they nevertheless determine a regional and local impact in the medium and long run. This is why, future municipal governance should foster development and improvement policies capable of granting the competitiveness on a global-scale network of this commercial hub whilst enhancing and promoting the territory's local identity. 


\section{References}

Anselmi, S. (1985). Dalla mezzadria all'industria: una conversione completa nelle Marche d’oggi. In Turing Club Italiano, Marche, Collana "Attraverso l'Italia”. Milano, TCI, 1985, 9-11.

Betti, S. (2002). L'uomo modificatore della superficie terrestre nella provincia di Pesaro e Urbino (1951-2001). Studi e Ricerche di Geografia, XXV, 111-225.

Betti, S., Nicosia, E., Porto C.M. (2011). Polycentrism in the Marche Region, a strategic factor for a competitive development in sustainability. In Prezioso M. (Ed.). Competitiveness in sustainability: the territorial dimension in the implementation of Lisbon/Gothenburg process in Italian Regions and Provinces. Bologna, Pàtron, 197-225.

Betti, S., Porto, C.M. (2010). Il commercio ambulante nella città contemporanea marchigiana, analisi e prospettive di sviluppo nella provincia di Macerata. Geotema, 38, 18-29.

Bonavero, P. (2005). L’approccio transcalare come prospettiva di analisi. Il contributo della geografia alla ricerca economica e sociale. Milano, EDUCatt Università Cattolica.

Bullado, E. (2007a). Il commercio nel centro storico: un "personaggio" in cerca di autore. Rivista Geografica Italiana, CXIV, 3, 427-440.

Bullado, E. (2007b). La "Rivoluzione Commerciale" in Italia: un po' di storia. In Cirelli C. (Ed.). Gli spazi del commercio ne processi di trasformazione urbana. Bologna, Pàtron, 27-39.

Bullado, E. (2009). Non solo shopping. La valutazione dello stato di salute del centro storico cittadino nell'esperienza anglosassone. Geotema, 38, 30-41.

Cachinho, H. (2011). Urban Retail Dynamics: from shopping spaces to consumer places. In Barata Salgueiro T., Cachinho H. (Eds.). Retail Planning for the Resilient City: consumption and urban regeneration. Lisbon, Centro de Estudos Geogràficos, 147-168.

Carreras, C., García Ballesteros, A., (2006). Geografía y consumo. In Hiernaux D., Lindon A., Tratado de Geografia Humana. Anthropos, Mexico City, 320-336.

Cavoto, G., Limonta, G. (2015). Dismissione commerciale. Dinamiche, strategie e programmazione. In D'Alessandro L. (Ed.). City, Retail and Consumption. Napoli, Università degli studi di Napoli "L’Orientale", 319-328.

Cirelli, C., Graziano, T., Mercatanti, L., Nicosia, E., Porto, C.M. (2014). A new dialetics centre/periphery: consumption patterns and practices in the suburban areas. Cidades, 11, 18, 289-309.
Cirelli, C., Graziano, T., Mercatanti, L., Nicosia, E., Porto, C.M. (2015). Costi sociali e ambientali nelle scelte localizzative della GDO. In D’Alessandro L. (Ed.). City, Retail and Consumption. Napoli, Università degli studi di Napoli "L'Orientale", 259-291.

Cirelli, C., Graziano, T., Mercatanti, L., Nicosia, E., Porto, C.M. (2016). Rileggendo la città: le recenti trasformazioni del commercio a Catania. Geotema, 51, pp. 48-59.

D’Alessandro L. (Ed.). City, Retail and Consumption. Napoli, Università degli studi di Napoli "L'Orientale".

Ilardi, M., (2004). Nei territori del consumo totale. Il disobbidiente e l'architetto. Roma, DeriveApprodi.

Meini, M., Monheim, R. (2002). Il commercio al dettaglio nei centri storici italiani fra tradizione e modernità. Rivista Geografica Italiana, CIX, 543-570.

Miani, F. (2001). Paesaggi urbani in trasformazione: nuova cultura e valori nelle città del ventunesimo secolo. Geotema, 14, 14-46.

Musso, F. (2012). Modelli di sviluppo degli insediamenti commerciali e implicazioni per le politiche regionali. In Gregori G.L., Pencarelli T. (Eds.). Economia, management e disciplina del commercio in Italia e nelle Marche. Milano, FrancoAngeli, 159-182.

Nicosia, E., Graziano, T., Porto, C.M. (2019). Il commercio nelle aree urbane marchigiane tra vecchi e nuovi format. Milano, FrancoAngeli.

Nicosia, E., Porto C.M. (2015). Spazi del consumo e nuove polarità commerciali nelle Marche: riflessioni e criticità. In D’Alessandro L. (Ed.). City, Retail and Consumption. Napoli, Università degli studi di Napoli "L'Orientale", 167-185.

Porto, C.M. (2007). Lindagine empirica sul contesto commerciale catanese. In Cirelli C. (Ed.). Gli spazi del commercio ne processi di trasformazione urbana. Bologna, Pàtron, 113-148.

Porto, C.M. (2016). Catene commerciali e franchising monomarca in tempo di crisi: verso la standardizzazione dei centri storici italiani? Geotema, 51, 139-144.

Porto, C.M. (2019). Spazi del consumo, gerarchie commerciali e processi di territorializzazione nelle Marche policentriche. In Nicosia E., Graziano T., Porto C.M., Il commercio nelle aree urbane marchigiane tra vecchi e nuovi format. Milano, FrancoAngeli, 115-160.

Zanderighi, L., Tamini, L. (2018). Dismissioni commerciali e resilienza. Nuove politiche di rigenerazione urbana. Milano, Egea. 